\title{
RECUPERAÇÃO JUDICIAL DA EMPRESA: UM BREVE ENSAIO JURÍDICO DO CENÁRIO ATUAL
}

\author{
COMPANY JUDICIAL RECOVERY: \\ A BRIEF LEGAL TEST OF THE CURRENT SCENARIO
}

ANTÔNIO CARLOS DINIZ MURTA ${ }^{1}$

NANY PAPASPYROU MARQUES MENDES ${ }^{2}$

\section{RESUMO}

A crise econômica, financeira e sanitária provocada pela pandemia do coronavírus convida a comunidade jurídica para um novo ciclo de estudos sobre os impactos do novo mundo no direito brasileiro, notadamente o empresarial. Depois de um exame sobre a construção do sistema jurídico falencial e recuperacional, com abordagem até de regra específica, o estudo propõe a aplicação de institutos do direito civil, ramo das obrigações e contratos, no curso da ação de recuperação, muito em especial para conferir o direito de revisão do plano contratado, sob as influências do novo estado de coisas, imposto por fato imprevisível e extraordinário, conforme Teoria da Imprevisão.

Palavras-chave: Recuperação Judicial. Natureza Jurídica. COVID-19. Direito Empresarial.Falência.

\section{ABSTRACT}

The economic, financial and health crisis caused by the coronavirus pandemic invites the legal community to a new cycle of studies on the impacts of the new world on Brazilian law, notably corporate law. After examining the construction of the bankruptcy and recovery system, with a specific rule approach, the study proposes the application of civil law institutes, branch of obligations and contracts, in the course of the

1 Graduação em Direito pela Faculdade de Direito da Universidade Federal de Minas Gerais (1987). Especialização em Direito Comercial pela Faculdade de direito da Universidade Federal de Minas Gerais (1994). Doutorado em Direito Comercial pela Faculdade de Direito da Universidade Federal de Minas Gerais (2000). Procurador do Estado lotado na Procuradoria de Tributos e Finanças de MG (PTF), órgão integrante da Advocacia Geral do Estado de Minas Gerais (AGE/MG). Coordenador da Procuradoria de Tributos e Finanças (PTF), da Advocacia Geral do Estado de Minas Gerais (AGE/MG) junto ao Conselho de Contribuintes de Minas Gerais (CC/MG). Membro/Conselheiro eleito do Conselho Superior da Advocacia Geral do Estado de Minas Gerais (AGE/MG). Membro da Comissão Permanente de Revisão e Simplificação da Legislação Tributária do Estado de Minas Gerais, no âmbito da Secretaria da Casa Civil e Relações Institucionais e da Secretaria de Estado da Fazenda. Professor Titular da Faculdade de Ciências Humanas, Sociais e da Saúde (FCH), unidade integrante da Fundação Mineira de Educação e Cultura / Universidade FUMEC. Lattes: http://lattes.cnpq.br/5206258464220367. ORCID iD: https://orcid. org/0000-0002-9568-7997. E-mail: acmurta@fumec.br

2 Mestranda em Direito pelo PPGD da FUMEC. Bacharel em Direito pela Universidade do Estado de Minas Gerais - UEMG (2013). Especialista em Direito Público pela Universidade FUMEC (2017). ORCID iD: https://orcid.org/0000-0001-95316996. E-mail: nanypmarques@gmail.com 
recovery action, especially in order to check the right to review the contracted plan, under the influence of the new state of affairs, imposed by an unpredictable and extraordinary fact.

Keywords: Judicial recovery. Legal Nature. COVID-19. Business Law. Bankruptcy.

\section{INTRODUÇÃO}

Daquilo que não se pode duvidar, está a certeza que a pandemia do corona-vírus marcou a vida da população mundial no ano de 2020. Situações novas, futuro que se mostra desconhecido e distante. A economia, por claro, transmudou-se ante ao reflexo das situações geradas pela propagação do vírus no mundo, e, é claro, no Brasil. A atividade empresarial, essência da economia capitalista, experimentou consequências variadas neste tempo pandêmico novo.

Alguns segmentos se viram diante de um mundo de oportunidades e ganhos. Outros, impossibilitados-limitados/obstados de exercício, pela recomendação de não agrupamento de pessoas, como no entretenimento, nos transportes coletivos Assim, nstituições empresariais já acometidas por dificuldades financeiras vinham sob tratamento do processo de recuperação regulado pela lei 11.101/2005, e também decerto impactados pelos corolários da pandemia. Estas empresas provavelmente necessitarão de uma revisão ao plano recuperacional para que possam efetivamente se recuperarem

A alternativa normativa para o incumprimento de obrigação pactuada no plano de recuperação é a convolação para a ação de falência. Com o suporte nos princípios que orientam a construção do direito falimentar, o texto que se apresenta, por seu turno, propõe a possibilidade de uma revisão do plano de recuperação em curso, se as obrigações nele inseridas se tornarem desequilibradas, onerosas. Para tanto, a exploração da doutrina jurídica que confere ao plano recuperacional a natureza de contrato, conduz e fundamenta a construção científica deste artigo.

A partir de um breve esforço histórico, e com visitas às regras e demais normas da lei recuperacional, a ideia que se propõe a construir, é a partir da aplicação de preceitos do direito privado obrigacional e contratual, na solução das questões exsurgidas deste e outro contexto inevitável, imprevisível e extraordinário.

\section{O SISTEMA DE INSOLVÊNCIA NO ORDENAMENTO JURÍDICO BRASILEIRO}

No ano de 2005, o Brasil inaugurou o seu novo regime jurídico de insolvência, o que se deu com a entrada em vigor, no dia 10 de junho daquele ano, da lei 11.101/2005, esta, sancionada e publicada em 9 de fevereiro também do ano de 2005.

A nova lei se propôs a regular a recuperação judicial, a extrajudicial e a falência do empresário e da sociedade empresária, substituindo-se, assim, os institutos da concordata 
preventiva e suspensiva previstas no Dec. Lei $7661 / 45$ pelos novos institutos então trazidos à lume pela nova lei, quais sejam a Recuperação Judicial e Extrajudicial das empresas em crise.

Em sendo empresário ou sociedade empresária o devedor, havendo o enquadramento da circunstância em um dos permissivos previstos no artigo 94 da Lei 11.101/2005 ${ }^{3}$, configurado está o estado falimentar apto a dar azo aos procedimentos liquidatórios específicos do processo concursal.

De outro lado, a nova lei, elaborada sob a realidade do comércio e indústria brasileiros no início do século XXI, ousou integrar no sistema de insolvência nacional o novo instituto da recuperação das empresas, tanto na via judicial quanto extrajudicial.

Tal instituto, especialmente quando comparado à pretérita concordata, tem alcance ampliado de seus efeitos em relação aos credores e ao próprio propósito da medida, a recuperação judicial das empresas tem como escopo viabilizar a superação da crise econômico financeira, permitindo-se a manutenção da fonte produtora, o emprego dos trabalhadores, os interesses dos credores, tudo com vistas à promoção da preservação da empresa, sua função social e o estímulo à atividade econômica, conforme artigo 47 da citada lei 11.101/20054

0 atual sistema de insolvência adotado pelo legislador nacional, desse modo, inaugurou no Brasil a importância destacada à atividade empresarial, de modo que o instituto da recuperação judicial da empresa tem como fundamento normativo principiológico e visa promover a própria preservação e função social da empresa e, ainda, estimular a atividade econômica.

Acredita-se, neste sentido, que o regime jurídico da insolvência atenda aos interesses dos agentes envolvidos na atividade empresarial, dando-Ihes soluções que possam atendê-los de modo satisfatório nas circunstâncias em que a crise econômica e financeira aflija a tranquilidade negocial então existente, isto, seja nas medidas liquidatórias realizadas no

3 Art. 94. Será decretada a falência do devedor que: I - sem relevante razão de direito, não paga, no vencimento, obrigação líquida materializada em título ou títulos executivos protestados cuja soma ultrapasse o equivalente a 40 (quarenta) salários-mínimos na data do pedido de falência; II - executado por qualquer quantia líquida, não paga, não deposita e não nomeia à penhora bens suficientes dentro do prazo legal; III - pratica qualquer dos seguintes atos, exceto se fizer parte de plano de recuperação judicial: a) procede à liquidação precipitada de seus ativos ou lança mão de meio ruinoso ou fraudulento para realizar pagamentos; b) realiza ou, por atos inequívocos, tenta realizar, com o objetivo de retardar pagamentos ou fraudar credores, negócio simulado ou alienação de parte ou da totalidade de seu ativo a terceiro, credor ou não; c) transfere estabelecimento a terceiro, credor ou não, sem o consentimento de todos os credores e sem ficar com bens suficientes para solver seu passivo; d) simula a transferência de seu principal estabelecimento com o objetivo de burlar a legislação ou a fiscalização ou para prejudicar credor; e) dá ou reforça garantia a credor por dívida contraída anteriormente sem ficar com bens livres e desembaraçados suficientes para saldar seu passivo; $f$ ) ausenta-se sem deixar representante habilitado e com recursos suficientes para pagar os credores, abandona estabelecimento ou tenta ocultar-se de seu domicílio, do local de sua sede ou de seu principal estabelecimento; g) deixa de cumprir, no prazo estabelecido, obrigação assumida no plano de recuperação judicial. §1 o Credores podem reunir-se em litisconsórcio a fim de perfazer o limite mínimo para o pedido de falência com base no inciso I do caput deste artigo. § 20 Ainda que líquidos, não legitimam o pedido de falência os créditos que nela não se possam reclamar. § 3o Na hipótese do inciso I do caput deste artigo, o pedido de falência será instruído com os títulos executivos na forma do parágrafo único do art. 90 desta Lei, acompanhados, em qualquer caso, dos respectivos instrumentos de protesto para fim falimentar nos termos da legislação específica. § $40 \mathrm{Na}$ hipótese do inciso II do caput deste artigo, o pedido de falência será instruído com certidão expedida pelo juízo em que se processa a execução. § $50 \mathrm{Na}$ hipótese do inciso III do caput deste artigo, o pedido de falência descreverá os fatos que a caracterizam, juntando-se as provas que houver e especificando-se as que serão produzidas. (BRASIL, Lei 11.101, de 9 de fevereiro de 2005. Disponível em: http://www.planalto.gov.br/ccivil_03/_ato2004-2006/2005/lei/l11101.htm. Acesso em 20 set. 2020)

4 Artigo 47: A recuperação judicial tem por objetivo viabilizar a superação da crise econômico-financeira do devedor, a fim de permitir a manutenção da fonte produtora, do emprego dos trabalhadores e dos interesses dos credores, promovendo, assim, a preservação da empresa, sua função social e o estímulo à atividade econômica. (BRASIL, Lei 11.101, de 9 de fevereiro de 2005. Disponível em http://www.planalto.gov.br/ccivil_03/_ato2004-2006/2005/lei/l11101.htm. Acesso em 20 set. 2020 
processo concursal falimentar, seja no tocante às medidas de soerguimento efetivadas no procedimento de recuperação da empresa viável.

A propósito, a atividade comercial e industrial, no mais das vezes, realiza-se com a oferta de crédito por parte dos agentes investidores de capital, assim, a indústria financia a sua produção sob a premissa de que o resultado havido com a venda dos produtos ou do serviço depreenda-se suficiente para honrar as obrigações com os investidores e, ainda, remunerar satisfatoriamente o trabalho e o capital empregados. Quando esta perspectiva de ordem mercadológica se frustra, idem aos dias de hoje, o sistema jurídico de insolvência há de entrar em cena, para assegurar a reordenação do cenário negocial e empresarial.

O não cumprimento da obrigação creditícia que, não raro, decorre do acometimento da crise no ambiente empresarial, fato de conhecimento notório e muito presente neste histórico ano de 2020, deve ser resolvido a partir do sistema legal de insolvência adotado pelo ordenamento jurídico de regência, seja pela falência, seja pelas modalidades de recuperação instituídas no regime jurídico mercantil.

Frederico A. Monte Simionato, em lição precisa sobre o imperativo de garantias que deve oferecer o regime jurídico da insolvência em favor daqueles envolvidos na atividade negocial, explica que:

"(...) em tempos em que se fala tanto do interesse da empresa, preservação da entidade produtora, não se pode olvidar, sob pena de riscos incríveis, a necessidade de satisfação dos interesses dos credores. 0 crédito é aquilo que de mais essencial existe no sistema capitalista (...)". (SIMIONATO, 2008, p.23)

Visto isso, claro está que o sistema de insolvência vigente pela Lei 11.101/2005 regula o processo liquidatório clássico, adotando como elemento configurador do estágio falimentar a insolvência jurídica, isto, por inteligência do artigo 94 da lei. A mesma norma, como sabido, ainda instituiu os procedimentos de recuperação judicial e extrajudicial das empresas em crise econômica, desde que ainda viáveis financeiramente, fato que enaltece sobremaneira a preocupação do legislador moderno aos interesses e função social da empresa e a sua utilidade no mercado que integra.

\section{A RECUPERAÇÃO JUDICIAL DE EMPRESAS}

A lei 11.101/2005, além dos preceitos liquidatórios típicos para as empresas inviáveis e que estejam em estágio falimentar, regula ainda e principalmente o procedimento da recuperação judicial da empresa em crise, este apto a garantir e preservar a participação social dos agentes envolvidos na atividade empresarial, em especial os credores (SIMIONATO, 2008).

Esta nova característica normativa, que prestigia a proteção dos interesses sociais que interligam as relações havidas no exercício da empresa, propõe a preservação da atividade empresarial viável e a obediência respectiva à sua função social e o estímulo da atividade econômica, isto, sabidamente, para que se permita a manutenção do núcleo produtivo, do emprego dos trabalhadores e, por óbvio, dos interesses dos credores. 
Neste sentido, o isolado interesse e desejo do empresário consistente no exercício da empresa em crise e de forma temerária cede lugar ao aspecto e relevo social que se depreende da atividade empresarial, isto, para que se determine como pressuposto para a concessão da medida recuperatória, a cuidadosa pesquisa e exame de sua essencial viabilidade financeira. ${ }^{5}$

A recuperação judicial das empresas, desse modo, conta com o fundamento na norma do artigo 47 da Lei 11.101/2005, na medida em que tal norma alcança e tutela os principais interesses expostos à situação da crise empresarial.

A redação da norma citada, como dito, regula e tutela os interesses de todos os agentes envolvidos na relação empresarial, isto é, na medida em que a norma prevê o instituto da recuperação como sendo apto à superação da crise empresarial, para que se permita a manutenção da fonte produtora, dos empregos dos trabalhadores, dos interesses dos credores, tudo com vistas à promoção da preservação da empresa viável e sua função social e, ainda, do estímulo à atividade econômica, está o legislador direcionando o espírito da lei à ideia da empresa institucional que atua em prol de todo o público que em suas relações encontra-se vinculado. ${ }^{6}$

Com efeito, a recuperação judicial das empresas é o instituto previsto no regime jurídico da insolvência e que, alicerçado em fortes princípios e fundamentos, propõe e regula o vencimento contra a crise e a reconstrução, reorganização, recuperação da empresa, de modo que sejam satisfatoriamente atendidos os interesses sociais que interligam as relações jurídicas havidas no seio do negócio.

O sucesso da medida de recuperação promove a preservação da empresa, sua função social e o estímulo à atividade econômica, conforme dispõe o artigo 47 da Lei 11.101/2005:

Art. 47. A recuperação judicial tem por objetivo viabilizar a superação da situação de crise econômico-financeira do devedor, a fim de permitir a manutenção da fonte produtora, do emprego dos trabalhadores e dos interesses dos credores, promovendo, assim, a preservação da empresa, sua função social e o estímulo à atividade econômica. (gn) (BRASIL. 2005)

A participação efetiva dos credores na sorte ou revés da proposta de recuperação da empresa ofertada pelo devedor também registra o marco social da atividade empresarial e, a sua respectiva utilidade no meio em que está integrada, em especial no tocante à redução

5 "Na busca dos fins sociais da empresa, não pode a administração da sociedade determinar políticas gerenciais contrárias ao interesse da companhia, e neste passo se fala em interesse geral de todos os fatores que compõem a empresa, como empregados, consumidores, Estado, etc., ainda mais nos casos de gestão temerária ou fraudulenta, lesando o interesse dos credores. Com efeito, o interesse social deve ser o interesse da companhia, e da própria coletividade, conforme art. 170 da Constituição Federal e arts. 115, 116, 117, 153-159 da Lei das S.A. Certamente, o fundamento do novo direito falimentar está na preservação da empresa viável financeiramente, e que significa a reformulação da forma de tratamento da empresa em dificuldades econômicas, colocando todos os interesses, nela representados na atividade empresarial, em uma situação complexa de fornecer, cada qual conforme suas forças e condições, instrumentos jurídicos e financeiros ao processo de reconstrução do fator produtivo". (SIOMIONATO, Frederico Augusto Monte, 1972 - Tratado de direito falimentar / Frederico A. Monte Simionato. - Rio de Janeiro, Forense, 2008, p. 17-18)

6 "A definição legal é realmente correta. Os magistrados devem se atentar que reside aqui, no art. 47 da nova Lei, a fonte de interpretação e aplicação do novo direito falimentar, como norma definidora de deveres, funções e paradigmas de hermenêutica jurídica, fazendo valer o interesse público sobre o interesse individual dos credores, e, portanto, repercutindo sobre a análise de viabilidade econômica do plano de recuperação judicial. (SIMIONATO, Frederico Augusto Monte, 1972 - Tratado de direito falimentar / Frederico A. Monte Simionato. - Rio de Janeiro, Forense, 2008, p. 122) 
do custo de crédito para o financiamento da produção e circulação de bens e serviços em virtude da atividade econômica empresarial organizada. ${ }^{7}$

A recuperação judicial das empresas brasileiras, então, é o instituto do direito falimentar que busca ofertar e garantir ao empresário ou sociedade empresária em crise econômica, meios hábeis de soerguimento e superação da crise.

Todavia, nem todos os devedores estão aptos ao manejo da ação, já que, a mesma consiste claramente na socialização dos riscos do negócio junto aos credores existentes ao tempo da medida e, tal distribuição de riscos não pode ser feita em prol de empresas inviáveis e irrecuperáveis.

Desse modo, apenas devem servir-se do instituto da recuperação da empresa as atividades ainda viáveis financeiramente e que, uma vez recuperadas, possam restituir à sociedade os prejuízos e sacrifícios expendidos para o seu salvamento.

Nesta linha, o devedor empresário que identificar e assumir a situação de crise econômico financeira pode buscar o processamento da medida judicial de recuperação, devendo o Poder Judiciário, neste caso, aferir com segurança a viabilidade demonstrada pelo devedor. Viável, portanto, é a empresa que detenha o conjunto de certos elementos, tais como a viabilidade financeira, importância e relevo social, mão de obra e tecnologia empregadas, porte econômico, exercício consolidado da atividade e maturidade para o mercado, dentre outros que a casuística exija a presença.Para a doutrina de Fábio Ulhoa COELHO, estão aptas a buscar o instituto de recuperação de empresas, as instituições empresariais que de fato e de direito reunirem condições de viabilidade para tanto. Veja abaixo:

\begin{abstract}
Somente as empresas viáveis devem ser objeto de recuperação judicial ou extrajudicial. Para que se justifique o sacrifício da sociedade brasileira presente, em maior ou menor extensão, em qualquer recuperação de empresa não derivada de solução de mercado, a sociedade empresária que a postula deve mostrar-se digna do benefício. Deve mostrar, em outras palavras, que tem condições de devolver à sociedade brasileira, se e quando recuperada, pelo menos em parte o sacrifício feito para salvá-la. Essas condições agrupam-se no conceito de viabilidade da empresa, a ser aferida no decorrer do processo de recuperação judicial ou na homologação da recuperação extrajudicial. (COELHO, 2011, p.404)
\end{abstract}

Na mesma trilha segue o raciocínio expendido por Frederico A. Monte SIMIONATO, que defende o necessário exame da viabilidade da empresa como pressuposto, fundamento da concessão da recuperação pelo Poder Judiciário. Para este jurista, as empresas que demonstrem irrecuperabilidade, inviabilidade, devem seguir o revés do procedimento liquidatório falencial, deixando para os auspícios do instituto da recuperação da empresa apenas aqueles devedores que demonstrem e convençam especialmente os seus credores de que a atividade empreendida é, seguramente, viável sob o ponto de vista econômico.

Eis a lição precisa da doutrina em referência:

7 "A Lei 11.101/05 deve ser interpretada do ponto de vista da sua utilidade econômica, como qualquer Lei de Falências. No capítulo da recuperação esta interpretação deve ser ainda mais forte. 0 órgão julgador deve saber que a prerrogativa da apresentação do plano é, por certo, do devedor, e que o crivo deste plano fica condicionado, única e exclusivamente, aos credores, na medida em que a natureza jurídica da aprovação do plano é concordatária, por maiorias legais". (SIMIONATO, Frederico Augusto Monte, 1972 - Tratado de direito falimentar / Frederico A. Monte Simionato. - Rio de Janeiro, Forense, 2008, p. 21). 
"A empresa somente deve ser socorrida caso ainda seja viável. Sociedades empresárias que porventura demonstrem fragilidade financeira e econômica, sem que se possa ao menos vislumbrar uma possibilidade séria de recuperação, deverão ser declaradas falidas, para o bem do crédito, que, em realidade, não pode ser dissipado em organismos inviáveis seja pela sua administração incompetente ou pelo volume do passivo". (SIMIONATO, 2008, p. 129)

Ademais, está a cargo do magistrado, do administrador judicial e até mesmo dos credores a verificação dos balanços, do plano de recuperação, enfim, da efetiva viabilidade da empresa, fato que denota a devida obediência ao Princípio da Preservação da Empresa Viável. ${ }^{8}$

Para a concessão da medida, o devedor empresário deve observar os pressupostos ditados pela Lei 11.101/05, quais sejam aqueles proclamados pelo artigo 48 da respectiva norma.

O devedor deve ainda expor na petição inicial as causas concretas da crise e da situação patrimonial, instruindo-a com os documentos contábeis exigidos na norma do artigo $51^{9}$ da afirmada lei de regência.

Sobre os meios de recuperação judicial, o legislador também listou, nada mais nada menos que 16 (dezesseis) opções ofertadas ao devedor em crise, estas, lançadas no texto do artigo 50 da regência normativa da lei 11.101/2005.

Profissionais de aptidão comprovada devem servir ao devedor na escolha da estratégia de salvamento, tais como economistas, contabilistas, administradores, analistas de mercado e, por juristas.

A recuperação, como pode ser visto, tem o escopo de tutelar não apenas os exclusivos e individuais interesses do empresário, mas sim, macro interesses de ordem coletiva e social,

8 "Este princípio é ponto de partida da aplicação da Lei 11.101/2005. 0 magistrado, juntamente com o administrador judicial deve verificar, analisando os balanços, a viabilidade daquela atividade empresarial. É certo que a aplicação da nova legislação merece cautela, para que se possa fazer valer o espírito da Lei, qual seja, a manutenção da empresa viável, e a verificação de viabilidade deve ser avaliada, mesmo preliminarmente, no deferimento ou não do processamento do plano de recuperação." (SIMIONATO, 2008, p. 130)

9 Art. 51. A petição inicial de recuperação judicial será instruída com: I - a exposição das causas concretas da situação patrimonial do devedor e das razões da crise econômico-financeira; II - as demonstrações contábeis relativas aos 3 (três) últimos exercícios sociais e as levantadas especialmente para instruir o pedido, confeccionadas com estrita observância da legislação societária aplicável e compostas obrigatoriamente de: a) balanço patrimonial; b) demonstração de resultados acumulados; c) demonstração do resultado desde o último exercício social; d) relatório gerencial de fluxo de caixa e de sua projeção; III - a relação nominal completa dos credores, inclusive aqueles por obrigação de fazer ou de dar, com a indicação do endereço de cada um, a natureza, a classificação e o valor atualizado do crédito, discriminando sua origem, o regime dos respectivos vencimentos e a indicação dos registros contábeis de cada transação pendente; IV - a relação integral dos empregados, em que constem as respectivas funções, salários, indenizações e outras parcelas a que têm direito, com o correspondente mês de competência, e a discriminação dos valores pendentes de pagamento; $V$ - certidão de regularidade do devedor no Registro Público de Empresas, o ato constitutivo atualizado e as atas de nomeação dos atuais administradores; VI - a relação dos bens particulares dos sócios controladores e dos administradores do devedor; VII - os extratos atualizados das contas bancárias do devedor e de suas eventuais aplicações financeiras de qualquer modalidade, inclusive em fundos de investimento ou em bolsas de valores, emitidos pelas respectivas instituições financeiras; VIII - certidões dos cartórios de protestos situados na comarca do domicílio ou sede do devedor e naquelas onde possui filial; IX - a relação, subscrita pelo devedor, de todas as ações judiciais em que este figure como parte, inclusive as de natureza trabalhista, com a estimativa dos respectivos valores demandados. § 10 Os documentos de escrituração contábil e demais relatórios auxiliares, na forma e no suporte previstos em lei, permanecerão à disposição do juízo, do administrador judicial e, mediante autorização judicial, de qualquer interessado.§ 20 Com relação à exigência prevista no inciso II do caput deste artigo, as microempresas e empresas de pequeno porte poderão apresentar livros e escrituração contábil simplificados nos termos da legislação específica.

§ 300 juiz poderá determinar o depósito em cartório dos documentos a que se referem os §§ 1o e 20 deste artigo ou de cópia destes. (BRASIL, Lei 11.101, de 9 de fevereiro de 2005. Disponível em: http://www.planalto.gov.br/ccivil_03/_ato20042006/2005/lei//11101.htm. Acesso em 20 ago. 2020) 
razão esta que justifica uma investigação e interpretação que vá ao encontro da verdadeira intenção e eficácia da ação recuperacional, dos seus princípios correlatos e do próprio sistema jurídico da insolvência.

Não pode ser considerada a empresa como atividade organizada apenas em prol dos interesses estritamente individuais do empresário, como sendo um bem de sua exclusiva propriedade que dela faz o que bem quer e deseja, pois, a empresa na atualidade serve à sociedade como pilar do seu equilíbrio econômico, do desenvolvimento social.

A Lei 11.101/2005, sensível à importância social da empresa e ao nocivo efeito da falência perante a sociedade, propõe uma nova interpretação e visão finalística em prol da manutenção e preservação da empresa, por isso, cede lugar a perspectiva meramente liquidatória da falência para a aplicação séria e segura da recuperação da empresa e, por conseguinte, a preservação e manutenção do núcleo produtivo. Proposta a medida, processada a causa, submetida à análise dos credores, a aprovação do plano confere à recuperação judicial a natureza jurídica de um contrato judicial de feição novativa.

Para a jurista Maria Celeste Morais Guimarães, o aspecto processual da medida recuperacional é destacada na definição, pois, para tal doutrina:

A recuperação judicial é uma ação judicial destinada a sanear a situação de crise econômico-financeira do devedor salvaguardando a manutenção da fonte produtora, do emprego de seus trabalhadores e os interesses dos credores, viabilizando, dessa forma, a realização da função social da empresa. (GUIMARÃES, 2007. p. 126)

$\mathrm{Na}$ definição de Alberto Caminã Moreira, $r$ também se vislumbra a ideia de um contrato a ser celebrado entre o devedor e os seus credores, estes, os destinatários da proposta constante do plano. Para aquela doutrina, a recuperação judicial consiste no direito do devedor de apresentar aos seus credores uma proposta, um plano, que poderá ou não ser aceita por eles. Não se trata, pois, de medida litigiosa, mas sim de um procedimento cuja causa de pedir é a proposta de superação da crise através da efetivação de um plano estratégico que será analisado e, aprovado ou rejeitado pelos credores. ${ }^{10}$

Afirma Joaquim Jorge Lobo, que a recuperação judicial tem natureza e características próprias do Direito Econômico, pois as normas que a regulam não visam resolver um conflito à luz do ideal de justiça, mas sim, oferecer soluções, meios e condições para que as empresas em estado de crise possam se reerguer e se reestruturar, de modo que possa voltar a cumprir sua função econômica e social na cadeia produtiva. ${ }^{11}$

10 Para Alberto Camiña: “Na recuperação judicial não há pretensão exercida contra os credores, entendida a pretensão como a afirmação de um direito contra o réu, para que seja este submetido a ele. 0 direito do devedor, na recuperação judicial, é de apresentar uma proposta, apresentar um plano. 0 destino do plano, contudo, está nas mãos dos credores, que poderão aceitá-lo, modificá-lo ou rejeitá-lo. [...] Negociação é a palavra chave; e essa negociação, conquanto se dê perante o Poder Judiciário, dá-se sem a intervenção do juiz. A lei não prevê a atuação jurisdicional para esse fim; muito embora o juiz brasileiro disponha de poderes gerais de conciliação, e ela seja mesmo muito enfatizada pela doutrina." (Ibid., p. 249-250).

11 Para Joaquim Jorge Lobo, "embora 'ato complexo' e 'ação constitutiva', a recuperação judicial tem natureza e as características de um instituto de Direito Econômico, como passo a demonstrar. Filio-me à doutrina, liderada, no País, por Orlando Gomes, que sustenta (a) estar o Direito Econômico situado numa zona intermediária entre o Direito Público e o Direito Privado, (b) possuir uma tríplice unidade: 'de espírito, de objeto, e de método' e (c) não orientar-se regra de direito pela idéia de justiça (princípio da igualdade), mas pela idéia de eficácia técnica devido à especial natureza da tutela jurídica que dela emerge, em que prevalecem interesses gerais e coletivos, públicos e sociais, que ela colima preservar e atender prioritariamente, daí o caráter publicístico de suas normas, que se materializam através de 'fato de príncipe', 'proibições legais' e 'regras excepcionais'. Com efeito, a recuperação judicial da empresa é um instituto de Direito Econômico, porque suas normas não visam precipuamente realizar a idéia de justiça, mas sobretudo criar condições e impor medidas que propiciem às empresas em estado de crise econômica se reestruturarem, ainda que com parcial sacrifício de seus credores". (LOBO, 
A doutrina em referência vê na recuperação judicial um instituto ligado ao Direito Econômico, notadamente porque a medida recuperacional tem o propósito de ofertar à empresa em crise meios que propiciem a reestruturação da atividade e, não diretamente a solução do caso sob a ideia precípua de justiça.

Marlon Tomazette, por seu turno, diz a recuperação judicial como um:

Conjunto de atos, cuja prática depende de concessão judicial, com objetivo de superar as crises de empresas viáveis. Assim, podemos estabelecer os elementos essenciais da recuperação judicial: (a) série de atos; (b) consentimento dos credores; (c) concessão judicial; (d) superação da crise; e (e) manutenção das empresas viáveis (TOMAZZETE, 2011, p.42)

O conceito elaborado pelo didático autor revela a recuperação judicial enquanto procedimento, contrato judicial e, ainda, o seu aspecto teleológico e principiológico.

\subsection{ESTUDO SOBRE A NATUREZA JURÍDICA}

$\mathrm{Na}$ leitura de sua natureza jurídica, os adeptos da doutrina privatista tendem a afirmar que a natureza jurídica da recuperação judicial é um contrato judicial. Os publicistas, que vêem na recuperação um instituto de direito público, afirmam que a recuperação judicial é um instituto do direito processual (LOBO, 2005, p.126).

Para Sérgio Campinho a recuperação judicial é um contrato judicial de feição novativa. É contrato que se celebra perante o poder judiciário e, depois de deferido o processamento da ação recuperacional, tal qual proclama a norma do art. 59 da Lei n. 11.101/2005, implica na novação dos créditos anteriores ao pedido.

Tomazette, segue a mesma linha que confere a natureza jurídica de contrato à recuperação judicial, e explica, ainda, que a atuação judicial presente no curso da ação recuperacional não desconfigura a sua feição contratual, pois o juiz é mero supervisor do procedimento.

O poder judiciário, portanto, não impõe a recuperação, ele só poderá concedê-la caso se chegue ao acordo entre os credores. Portanto, a recuperação judicial é um acordo de vontades entre o devedor em crise e seus credores, que se manifestam em conjunto, por meio da assembleia de credores, uma vez que possuem uma comunhão de interesses (TOMAZETTE, 2011).

Em que pese a autoridade dos argumentos sobre natureza jurídica da recuperação da empresa, o aspecto contratual da recuperação judicial da empresa salta aos olhos, na medida em que ele, o instituto, é examinado a par dos elementos jurídicos que configuram o contrato privado, e com a identificação de pontos que lhes são coincidentes - recuperação da empresa e contrato privado.

Não se pode desprezar, por óbvio, a importância e valor de outras construções jurídico cientificas que também definem a natureza jurídica da recuperação, mas de modo diferente.

A natureza processual, a propósito, é igualmente rica e fundada, desde que edificada a partir da constatação que a recuperação judicial é processada por meio do exercício do 
direito de ação, subordinada à jurisdição estatal do Poder Judiciário, portanto, eminentemente processual sua natureza.

A natureza contratual do instituto da recuperação da empresa, por sua vez, destaca-se a partir da existência de um plano viável de recuperação da empresa, realizado sob a presença da elaboração estratégica, apresentação aos credores, deliberações, alterações e aprovação (consenso) - elemento volitivo.

A declaração das vontades, geral, livre e consentida, de contratar um plano viável de recuperação judicial da empresa, é pressuposto fundante do instituto jurídico. Desse modo, revela-se clara a feição contratual da natureza jurídica da recuperação da empresa, pois tanto neste instituto, quanto nos contratos privados em geral, o acordo de vontades é requisito jurídico consagrado tanto no plano da existência, quanto da validade.

Na recuperação judicial, o devedor e credores "sentam-se a mesa" para efetivamente negociarem quanto aos laços obrigacionais que os vinculam, tudo isso, realizado ante o poder jurisdicional estatal, que conferem segurança e validade aos efeitos que do instituto recuperacional resultam.

Está presente, portanto, elementos coincidentes, de natureza contratual, na construção jurídico científica da recuperação judicial da empresa.

O direito das obrigações, regido pelo código civil, completa e normatiza o conteúdo dos contratos privados em geral, pois estes, os contratos, são essencialmente instrumentos de pactuação de obrigações, seja de fazer ou não, de entregar ou não, de satisfazer ou não. As obrigações pactuadas no cenário das operações negociais empresariais se concretizam nos contratos, os quais, erigem-se a partir das declarações volitivas, livres e consentidas.

Ainda, o artigo 47 da lei 11.101/2005, normatiza a preservação da empresa como objetivo legal da recuperação judicial da empresa. A preservação, do mesmo modo, é preceito que também normatiza os contratos em geral, na medida em que o ordenamento jurídico consagra a preservação dos contratos como postulado normativo que orienta a interpretação e execução das obrigações contratuais. No plano da ação recuperacional, a aprovação do plano, como sabido, produz novação das obrigações então celebradas, efeito este que também é próprio do direito privado das obrigações.

Dispõe a lei que: "Art. 59. O plano de recuperação judicial implica novação dos créditos anteriores ao pedido, e obriga o devedor e todos os credores a ele sujeitos, sem prejuízo das garantias, observado o disposto no $\S 1^{\circ}$ do art. 50 desta Lei".

No mesmo sentido, a aprovação do plano também vincula o devedor às obrigações insertas no plano, e se não cumprir qualquer delas, a convolação da ação recuperacional em falência é efeito já previsto na lei.

O vigor da lei, e a sedimentada doutrina e jurisprudência, firmaram consenso no sentido de que o plano, depois de aprovado, deve ser cumprido à risca pelo devedor recuperando, sob pena de ser convolada a sua ação recuperacional em falência. Ainda, se passado o prazo de tramitação processual da ação, o incumprimento de obrigação ainda remanescente, no tempo e modo, justifica a causa de pedir para propositura de ação falimentar. Como se vê, aprovado o plano, ou o devedor em recuperação o cumpre, ou a sua falência há de ser fatalmente decretada. 
Prevê a lei:

Art. 61. Proferida a decisão prevista no art. 58 desta Lei, o devedor permanecerá em recuperação judicial até que se cumpram todas as obrigações previstas no plano que se vencerem até 2 (dois) anos depois da concessão da recuperação judicial.

$\S 1^{\circ}$ Durante o período estabelecido no caput deste artigo, o descumprimento de qualquer obrigação prevista no plano acarretará a convolação da recuperação em falência, nos termos do art. 73 desta Lei.

$\S 2^{\circ}$ Decretada a falência, os credores terão reconstituídos seus direitos e garantias nas condições originalmente contratadas, deduzidos os valores eventualmente pagos e ressalvados os atos validamente praticados no âmbito da recuperação judicial. (BRASIL, 2005)

No entanto, em tempos atuais, em que o mundo se vê avassalado pelos efeitos econômicos provocados pela pandemia do covid-19, decerto que as empresas buscarão as alternativas existentes para lhes proverem sobrevivência durante e após a crise instalada, em especial, a ação de recuperação.

Além disso, outras tantas empresas que já se encontravam em situação de recuperação são agora obrigadas a encontrar o ponto de equilíbrio capaz de garantir viabilidade para sua existência jurídica, ainda que num cenário fático certamente muito diferente daquele existente quando da construção do plano recuperacional.

Estas empresas se encontram sob a severidade do vigor normativo do sistema jurídico recuperacional e falimentar, obrigadas a cumprir um plano obrigacional elaborado, discutido e aprovado num contexto totalmente diverso. As estratégias eleitas, projetadas e elaboradas para garantir viabilidade e sucesso à recuperação, estão agora desafiadas por um novo, incerto, desconhecido e inesperado mundo.

Qual tratamento deve ser dispensado a estas instituições empresariais? Decretar a sua fatal falência sob o fundamento jurídico literal do texto normativo? Ou, lado outro, a par da regência dos princípios da preservação da empresa e dos contratos, da função social, dos interesses dos credores, a revisão do plano já aprovado poderia ser permitida, inclusive como uma releitura do instituto recuperacional.

Nesta linha, novamente a aceitação da recuperação judicial também em sua natureza contratual é necessária para que seja aplicada a teoria da imprevisão, própria das relações obrigacionais privadas, para garantir ao devedor em recuperação oportunidade para revisar o plano já aprovado, por óbvio, mediante a participação dos credores inclusive em nova assembleia.

Com amparo na teoria da imprevisão, nas hipóteses de incumprimento de obrigação por fato imprevisível e extraordinário, tal qual a ainda incomensurável crise do covid-19, o plano de recuperação judicial deve ser sujeito ao direito de revisão, para que seja proporcionado ao recuperando o reequilíbrio da situação, e o atingimento do objetivo sacro, a saber, a recuperação da empresa.

Sujeitar a lei 11.101/2005 a novo e atual exercício interpretativo, sob a batuta das garantias constitucionais sedimentadas no ordenamento, significa enquadrar o quadro fático real das circunstâncias a uma moderna interpretação e aplicação da lei recuperacional, para per- 
mitir a revisão judicial do plano aprovado, por meio de novo conclave e obediência aos ritos e garantias processuais.

Por meio de fundamento de essência, construído a partir da natureza jurídica contratual do plano recuperacional, permitir-se-ia a revisão do plano de recuperação da empresa, sob a regência conjunta e harmônica das leis privadas, notadamente as de natureza contratual e obrigacional, e das regras insculpidas no sistema jurídico recuperacional e falencial.

\section{CONSIDERAÇÓES FINAIS}

Vigora no Brasil, há quinze anos, um sistema jurídico falencial e recuperacional, tendo como objeto o regramento jurídico dos conflitos de crise empresarial, eminentemente, na atividade privada.

Referido sistema cuida de forma ampla do processo falencial, e também recuperacional das empresas em crise.

O conjunto destas normas foi instituído por conteúdo principiológico moderno, instituído no ambiente do século XXI. Está, aos quinze anos de vigência, e já com jurisprudência direcionada desafiado por um estado fático avassalado por uma pandemia sanitária, de saúde, financeira e econômica sem precedentes no mundo.

Nas linhas anteriores insertas ao longo deste estudo, a pretensão foi a de demonstrar a forte construção normativa do tema, seus aspectos históricos, gerais, e regramentos específicos, estes, trazidos para o desafio do mundo que nesta hora se apresenta. Eis a maior e sacra função do direito, qual seja, regular os conflitos sócio humanos.

É este o momento em que a doutrina do direito se dedica a pensar em soluções, com respaldo fundado, capazes de permitir a manutenção das empresas, sob atual e necessária releitura do sistema de leis.

Até hoje, o simples e imotivado incumprimento de obrigações do plano aprovado em assembleia transmuda, no dizer da lei, convola, quase que num passe automático, um projeto de recuperação de empresa em fatal processo de liquidação falencial e encerramento da atividade.

A revisão das obrigações contratadas própria do direito dos contratos privados, pode será aplicada na ação recuperacional, permitindo-se uma outra oportunidade de superação a empresa recuperanda, diante de um novo, extraordinário, e imprevisível mundo das coisas.

A proposta é nada mais, nada menos voltada à consagração dos princípios e objetivos do instituto, protagonistas deste sistema ora posta em xeque, a preservação e função social da empresa, zelo pelos interesses dos credores e manutenção da fonte produtora de empregos. revisão das obrigações contratadas no plano recuperacional, encontra fundamento no diálogo das fontes do direito civil - obrigações e contratos, com direito de empresa. 


\section{REFERÊNCIAS}

BARBOSA FILHO, Marcelo Fortes; PELUSO, Cezar (Coord.). Código Civil comentado. Doutrina e jurisprudência. 6. ed. Barueri: Manole, 2012.

BRASIL. Constituição (1988). Constituição da República Federativa do Brasil de 1988. Disponível em: http://www. planalto.gov.br/ccivil_03/constituicao/constituicao.htm. Acesso em: 20 ago. 2020.

BRASIL. Decreto-lei 7.661, de 21 de junho de 1945. Disponível em: http://www.planalto.gov.br/ccivil_03/decreto-lei/del7661.htm. Acesso em: 20 ago. 2020.

BRASIL, Lei n. 6.404 de 15 de dezembro de 1976. Dispõe sobre as sociedades por ações. Disponível em: http:// www.planalto.gov.br/ccivil_03/leis/I6404consol.htm. Acesso em: 20 ago. 2020.

BRASIL. Lei 10.406, de 10 de janeiro de 2002. Institui o Código Civil. Disponível em: http://www.planalto.gov.br/ ccivil_03/leis/2002/l10406.htm. Acesso em: 20 ago. 2020.

BRASIL. Lei n. 11.101, de 9 de fevereiro de 2005. Regula a recuperação judicial, a extrajudicial e a falência do empresário e da sociedade empresária. Disponível em: http://www.planalto.gov.br/ccivil_03/_ato2004-2006/2005/lei/ I11101.htm. Acesso em: Acesso em: 20 ago. 2020.

CAMPINHO, Sérgio. O Direito de Empresa à luz do novo Código Civil. 9. ed. Rio de Janeiro: Renovar, 2008.

CAMPINHO, Sérgio. Falência e recuperação de empresa: o novo regime da insolvência empresarial. 5. ed. Rio de Janeiro: Renovar, 2010.

COELHO, Fabio Ulhoa. Curso de Direito Comercial. 12. ed. São Paulo: Saraiva, 2011. v. 3: Direito de Empresa.

COELHO, Fábio Ulhoa. Curso de Direito Comercial. 17. ed. São Paulo: Saraiva, 2013. v. 1: Direito de Empresa.

DELGADO, José. Interpretação contemporânea da lei de recuperação judicial e sua aplicação ao produtor rural quando pratica atos empresariais. Revista de Direito Empresarial e Recuperacional, Florianópolis, v. 1, n. 0, p. 11-57, jan./mar. 2010.

GUIMARÃES, Maria Celeste Morais. Recuperação judicial de empresas e falências. Belo Horizonte: Del Rey, 2007.

LOBO, Jorge Joaquim. Direito da Empresa em crise: a nova lei de recuperação da empresa. Revista Forense, v. 379 , p. 119-131, maio-jun. 2005.

MOREIRA, Alberto Camiña. Poderes da assembleia de credores, do juiz e atividade do Ministério Público. In: PAIVA, Luiz Fernando Valente de (Coord.). Direito Falimentar e a nova lei de falências e recuperação de empresas. São Paulo: Quartier Latin, 2005.

SIMIONATO, Frederico Augusto Monte. Tratado de Direito Falimentar. Rio de Janeiro: Forense, 2008.

STAJN, Rachel; PITOMBO, Antônio Sérgio A. de Moraes (Coord.). Comentários à Lei de Recuperação de Empresas e Falências: lei 11.101/2005 - artigo por artigo. 2. ed. São Paulo: Revista dos Tribunais, 2007.

TOMAZETTE, Marlon. Curso de Direito Empresarial. 4. ed. São Paulo: Atlas, 2012. v. 1: teoria geral e direito societário.

TOMAZETTE, Marlon. Curso de Direito Empresarial. São Paulo: Atlas, 2011. v. 3: Falência e recuperação de empresas.

Recebido/Received: 08.10.2020.

Aprovado/Approved: 03.12.2020. 